SELLCTION POUR LE IAIT CHEZ LE MOUTON

\author{
J. C. FLAMANT et F. BARILIET
}

Station d'Amélioration Génétique des Animaux, I.N.R.A., B.P. I2, 3Iз2o Castanet-Tolosan, France

La situation actuelle de la sélection des ovins laitiers et 1'évolution des schémas d'amélioration génétique sont décrits et analysés en insistant sur le double caractère de cette catégorie d'animaux : des animaux laitiers, des Ovins. Concernant des animaux laitiers les schémas d'amélioration génétique sont orientés prioritairement vers l'augmentation du niveau de production laitière. S'agissant d'Ovins il faut tenir compte également d'autres caractères tels que par exemple : l'adaptation aux contraintes de systèmes d'élevage où le niveau d'alimentation n'est pas à l'optimum durant toute l'année, la production de la laine, les caractéristiques de reproduction susceptibles d'une marge de progrès importante (prolificité, désaisonnement). De même des efforts sont à réaliser dans le sein d'une simplification du contrôle laitier pour abaisser son coût relativement au faible niveau des performances individuelles. En fin les caractéristiques biologiques de l'espèce conduisent à limiter le développement de l'insémination artificielle qui de toute manière reste toujours associée dans les troupeaux et dans les schémas de sélection à la monte naturelle.

\title{
GROUP BREEDING SCHEMES IN NEW-ZEALAND
}

\section{A. L. RAE}

Massey University, Palmerston North N.Z.

Group breeding schemes involve the screening of high-producing animals from contributing flocks into a nucleus flock. The nucleus flock in turn supplies rams to the contributing (and often other) flocks. Most of the schemes which have developed in New Zealand since I967 have the major objective of improving reproductive rate in Romney, Perendale and Coopworth sheep. The success of group breeding schemes in New Zealand has been partly due to their concentration on simple criteria of productivity for screening ewes and from the interest of commercial farmers in recording and selecting for improved production.

\section{CO-OPERATIVE GROUP BREEDING SCHEMES FOR PROLIFIC LOWLAND SHEEP BREEDS}

\section{J. B. OWEN and G. L. WILLIAMS}

\author{
Department of Agriculture, U.C.N.W., Bangor, Wales
}

Genetic improvement of commercial characteristics within individual lowland pedigree flocks is limited by the small size od such flocks. Increasing the number of recorded aninials in a population through continuous co-operation between breeders in conjunction with the formation of a nucleus flock, based on consistently high producing ewes, can provide a source of superior sires for the contributing flocks. The sheep breeding groups screening over a half a million ewes for twinning and easy lambing were operating in NZ in I976. A Weslh mountain sheep group (C.A.M.D.A. C.Y.N.W.Y.I.) formed in $197^{6}$ has its nucleus flock at an A.B.R.O. farm.

Progress should be more rapid in lowland prolific flocks where a high proportion of ewes breed in their first year and selection pressure can be high on the female side. Objective selection can be based on performance records collected by M.L.C. Two group breeding schemes with Cambridge and Llyn sheep are operated by U.C.N.W., Bangor.

\section{Cambridge}

The aim of this project is to form a new breed to fill the gap in the U.K. for a highly prolific dam-line breed. British breeds were screended in the early 6o's for the most highly prolific ewes based on 3 year records. A co-operative group breeding scheme was started in I969 
by the setting-up of ro flocks from breeding stock from the central flock. The nucleus flock is now situated at the University Farm, Bangor. Body weight of ewes is $70 \mathrm{~kg}$, littersize is I.9 for I year old and 2.9 for mature ewes as an average for all recorded females.

\section{Liyn group}

While the Llyn breed is at present of little importance nationally, with only about 4 ooo breeding ewes it possesses the attributes of high prolificacy, precociousness, good milk yield and acceptable meat type conformation. Mean weight of mature white-faced is $53 \mathrm{~kg}$, recorded litter size ranges from I.23 at I year old to I.96 for mature ewes (M.L.C. I978). Twelve breeders recording their flocks with M.L.C. formed a group breeding scheme in 1978 and the nucleus flock of 60 ewes is maintained at the University Farm. Breeding objectives are 200 per cent live lambs reared and mean weight of twin lambs at 8 weeks $20 \mathrm{~kg}$. The structure and operation of the groups will be discussed.

CURRENT APPLICATION OF AND EFFORTS TOWARDS SELECTION STRATEGIES IN CZECHOSLOVAKIA BASED ON RAM AND FWE SELECTION

\section{JAKUBEC}

\section{Research Institute of Animal Production, Praha, Io}

The emphasis of breeding activities in Czechoslovakia is given on a within elite and multiplier flock selection. Lambs selection is based on the lamb's own performance according to the weaning weight, conformation and quantitative and qualitative wool production. The breeding values of rams and ewes are evaluated on a flock basis by the means of an index in which the same traits as in the lambs are included. In this time the existing progeny testing stations are successively transferred to ram performance testing stations.

\section{METHODS OF INDEPENDENT CULLING LEVEIS OF SELECTION INDEX} IN THE ESTIMATION OF POLISH MERINO BREEDING VALUE

\section{J. KLEWIEC and M. J. RADOMSKA}

\section{Warsaw University of Agriculture, Institute of Biological Basis of Animal Breeding}

A comparison of two methods for selection : the independent culling levels and the selection index, with regard to two characters of wool productivity, namely fleece weight and staple length. With data on I 763 ewes in hand, we have worked out premises for selection by the independent culling levels technique and by the selection index $I=6.9504 X_{1}+3.6630 X_{2}$. The results obtained point out at a similar efficiency of both methods. Regarding fleece weight, the genetic gain expected on application of the former method is $0.12 \mathrm{~kg}$, while of the latter method - $0.13 \mathrm{~kg}$. Regarding the staple length, the respective values are 0.08 and $0.09 \mathrm{~cm}$. Having a scare number of characters to deal with, the independent culling levels method seems more useful.

\section{ESTIMATION OF BREEDING VALUE IN ICELANDIC SHEEP}

\section{S. HALLGRÍMSSON and J. V. JONMUNDSSON}

\section{The Agricultural Society of Iceland, Baedahöllin, P.O. Box 708o Reykjavik, Iceland}

The aim of this paper is to give a short description of the different computations done on the material from sheep recording in Iceland to make the results more useful to the breeder.

For better understanding of the different steps in correcting the data and the calculations there is a brief description of the sheep management, which might be of interest. It is also pointed out. that over 80 per cent of the income from sheep is derived from meat.

One of the greatest difficulties in using data from the sheep recording in Iceland is the different treatment of lambs after weaning and before slaughtering. This has been solved by 